\title{
THE AFFORDANCES OF THE FLIPPED CLASSROOM APPROACH IN ENGLISH GRAMMAR INSTRUCTION
}

\author{
Nguyen Huu Anh Vuong ${ }^{1}$ \\ Faculty of Psychology and Education, University Malaysia Sabah, Malaysia. \\ (Email: vuongnguyen@ufl.udn.vn) \\ Tan Choon Keong ${ }^{2}$ \\ Faculty of Psychology and Education, University Malaysia Sabah, Malaysia. \\ (Email: cktanums@gmail.com) \\ Lee Kean Wah ${ }^{3}$ \\ School of Education, University of Nottingham Malaysia Campus, Malaysia. \\ (Email: KeanWah.Lee@nottingham.edu.my)
}

Received date: $24-09-2019$

Revised date: $21-10-2019$

Accepted date: $22-10-2019$

Published date: 15-12-2019

To cite this document: Nguyen, H. A. V., Tan, C. K., \& Lee, K. W. (2019). The Affordances of The Flipped Classroom Approach in English Grammar Instruction. International Journal of Education, Psychology and Counseling, 4 (33), 95-106.

DOI: $10.35631 /$ IJEPC.433008

\begin{abstract}
Recently, the flipped classroom instructional approach has received much attention from teachers of different subjects around the world. This new pedagogical model has been reported to be a potential method in the area of EFL teaching. In Vietnam, teaching English grammar has mainly focused on students' acquisition of grammar rules without much practical application in real communicative situations. This case study aims at investigating the affordances perceived by students in a flipped English grammar class in order to help language teachers to harness the approach to enhance their students' learning. The qualitative research design was adopted in the study. Thirty-four students majoring in the English language at a university in Vietnam attended a 10-week flipped grammar class. The instruments include semistructured interviews with ten students randomly selected from the participants. Thematic analysis was performed to address the qualitative data drawing on the Activity Theory framework. Twelve affordances of the flipped classroom approach in English grammar instruction such as being self-paced in learning, offering opportunities to voice opinions, saving time for in-class communicative activities and facilitating learning English grammar communicatively were identified. The results of the study offer valuable implications for the application of this model in teaching English as a foreign language, especially in the context of Vietnam.
\end{abstract}

Keywords: Flipped Classroom Approach, EFL, Affordances, English Grammar Instruction 


\section{Introduction}

Vietnam, a developing country in Southeast Asia, is striving to proactively integrate into the global economy. English language is considered as one of the key elements to help this nation to closely connect to the outside world. Therefore, the ambitious National Foreign Language Project was launched by the government in an endeavour to renovate and promote EFL teaching and learning to enhance Vietnamese people's English language proficiency in the age of globalization. The project has produced a number of positive results in the area of English language education. Nevertheless, there have been some existing issues that need to be resolved so that all the objectives of the project could be achieved. For example, Le (2013) indicated that a lot of Vietnamese students have found difficulties in using English for communicative purposes. One of the causes to account for their poor English abilities is the outdated teaching methods which have been deeply rooted in educational settings (Le, 2013; Pham, 2011). Teacher-centred instructional methods instead of learner-centred ones have been prevailing in most of classrooms. It is thus necessary that new and innovative pedagogical teaching methods are encouraged and adopted by EFL teachers to improve the current situations.

As far as English grammar instruction is concerned, teaching mainly focuses on grammar knowledge rather than grammar use due to the prevalent adoption of the traditional grammar translation method (Ho and Binh, 2014). Students may master grammatical rules and do well in the exams but fail to apply those rules in real life communicative situations. In addition, several existing issues include insufficient time, large-sized classes, grammar-based examinations etc. might hinder communicative English grammar teaching. In normal grammar classes, teachers devote most of the class time to presenting grammatical rules through their lectures. They then require their students to complete controlled practice for structural accuracy. Almost no communicative activities are found in those classes to facilitate students' applying the newly acquired rules in real practice (Ho and Binh, 2014; Khuong, 2015). As a result, students are prevented from developing their communicative skills.

Flipped classroom has been recently introduced and successfully adopted in a variety of educational settings in many countries. With the aid of technology, this teaching method takes advantage of the benefits of both online learning and face-to-face learning. In flipped classes, lectures are moved out of the classrooms and the class time is mostly devoted to active learning activities. In the current research project, this new instructional model was employed in an attempt to address the existing issues associated with English grammar instruction. The study aims at investigating the affordances of the flipped classroom approach as perceived by the students. Identifying the affordances will enable EFL teachers to harness the teaching approach to enhance their students' learning. The following research question guided this study: "What are the affordances perceived by the students when learning English grammar in a flipped classroom?"

\section{Literature Review}

\section{Flipped Classroom}

Flipped classroom was first introduced by Dr Wesley Baker, a professor at Cedarville University in Ohio, USA. He posted the PowerPoint slides of his lectures on the university's computer network and asked his students to read them at home prior to class time. The class meetings were mostly reserved for applying and practicing the new concepts that the students had learned beforehand through collaborative activities (as illustrated in Figure 1). The teaching model proved to be successful in improving students' learning outcome (Baker, 2000). 


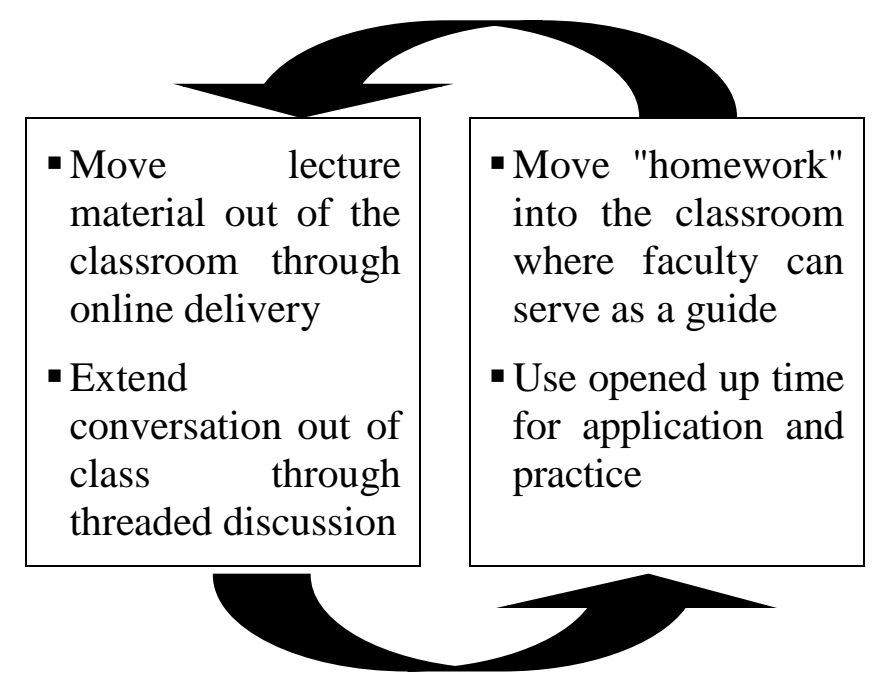

Figure 1: The Flipped Classroom Model (Baker, 2000)

As defined by Bishop and Verleger (2013), the flipped classroom is "a new pedagogical method, which employs asynchronous video lectures and practice problems as homework, and active, group-based problem-solving activities in the classroom" (p. 1). In the flipped classrooms, students learn knowledge ahead of time when watching lecture videos and accessing other online materials outside class. During class meetings, they practice what they have learned through active learning activities. Teachers normally work as monitors, facilitators and guides instead of knowledge providers. When studying at home via lesson videos, students can learn at their own speed since they can stop, rewind, and replay the videos as many times as needed. Repeated exposure to online lectures helps promote students' acquisition of the knowledge. In addition, active learning activities in which students apply what they have learned deepen their understanding of the lesson content. In the flipped classes, educational technologies play a crucial role. They help students acquire knowledge and become well-prepared before coming to class. The learning theory of constructivism serves as the theoretical basis for this teaching model (Bishop and Verleger, 2013).

Although there are different ways through which teachers could implement this pedagogical approach, the flipped classrooms normally share five core characteristics: (1) the educational process transforms students from passive to active learners; (2) technology facilitates the approach; (3) class time and traditional homework time are inverted so that homework is done first; (4) content is given in real-world context; (5) class activities engage students in higher order of critical thinking and problem solving or help them grasp particularly challenging concepts (Albert and Beatty, 2014). These characteristics work as guidelines for designing a flipped classroom.

Researchers have pointed out that the flipped classroom brings about numerous benefits. This teaching model results in better and more effective learning, improves learning outcomes, increases student engagement, aligns with student needs and school resources (Egbert, Herman, and Lee, 2015). Other benefits include saving more in-class time for active learning activities (Pape, Sheehan, \& Worrell, 2012), shifting learning environment from teacher-centred to student-centred (Gilboy, Heinerichs, \& Pazzaglia, 2015), increasing teacher-student and student-student interactions (Brunsell and Horejsi, 2013) and developing generic skills (McLaughlin et al., 2014). Yang (2017) also indicated that the flipped teaching model facilitated students' learning at their own speed, personalizing and individualizing process of learning, improving learning ownership, fostering reflective abilities, etc. Furthermore, most 
studies in the literature indicate that both teachers and students possess positive perceptions of this novel teaching method (El-Bassuony, 2016).

In the field of EFL education, the flipped classroom has proved to be effective as in other disciplines. Hung (2015) discovered that this teaching approach helped develop students' academic performance in an English course. Sung (2015) carried out a study to examine the adoption of the flipped classroom in an EFL course and found that this pedagogical approach could be a good momentum for change in current EFL teaching situations. Regarding specific language skills, the flipped teaching model demonstrates its effectiveness in enhancing students' writing (Ahmed, 2016), reinforcing listening comprehension (Kang, 2015), etc. In addition, it promotes other language areas such as grammar, vocabulary, and idiomatic knowledge (Chen Hsieh, Wu, and Marek, 2017). These researchers also found that the flipped classroom not only improves students' motivation and makes them more active in class but leads to their achieving class instructional goals as well.

In Vietnam, the flipped classroom teaching approach is relatively new to most teachers and educators. Some pioneering researchers have implemented this model in their classes and produced positive results, suggesting that the flipped classroom can be a potential teaching method in the Vietnamese educational context (Tran, 2017; Tran et al., 2017). The approach won favourable attitudes and positive perceptions from both teachers and students. Hence, the current research project aimed at investigating the adoption of this novel teaching model in English grammar instruction to identify its affordances in an attempt to make a modest contribution to the field.

\section{Activity Theory as the Framework for Data Analysis}

Started from the work of Vygosky and his student Leont'ev (Verenikina, 2001), Activity Theory is a conceptual framework based on the idea that activity is primary, that doing precedes thinking, that goals, images, cognitive models, intentions, and abstract notions like "definition" and "determinant" grow out of people doing things (Morf and Weber, 2000, p.81). Engeström (1987) modified the Vygoskys' original theory and popularised Activity Theory using the concept of a 'collective activity system'.

This theory uses the whole work activity as the unit of analysis, where the activity is broken into the analytical components or mediators including subject, object, tools, community, rules and division of labour. Each component has its own function and interacts with each other to build up an activity and relate to other components (Heo and Lee, 2013). Subject refers to the individual or a group of individuals involved in a collective activity while object is the objective of the activity and the intended product. The objective is then transformed into outcomes with the aid of tools or mediating artefacts. Tools are considered as the mediating devices by which the action is executed (Hasan, 1998). Community refers to a sociocultural context which comprises of numerous individuals that share common general objectives. Rules are explicit and implicit regulations, norms, and conventions that help to determine how and why individuals may act while division of labour provides for the distribution of actions and operations among a community.

With regards to the area of education, Activity Theory can be adopted to examine the implementation of learning supported by technology. In the current study, this theory was employed as the framework to analyse and identify the affordances of the flipped classroom (as illustrated in Figure 2). The flipped English grammar classroom is seen as an activity system. The outcomes towards which the activity is directed is the improvement of students' learning achievement and motivation. 


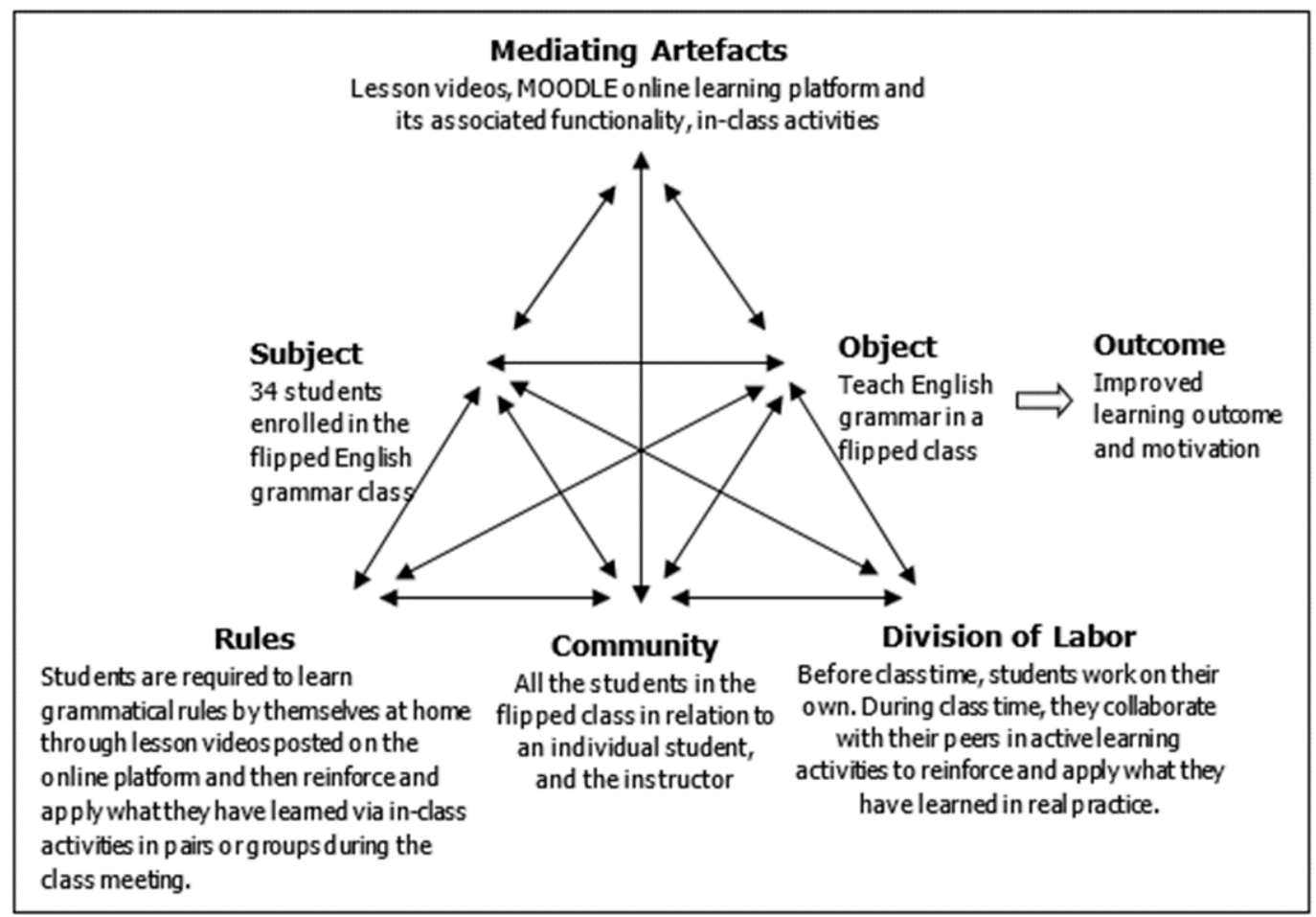

Figure 2: Activity Triangle Model of the English Grammar Flipped Classroom

\section{Methodology}

\section{Research Design}

A qualitative case study design was employed to investigate the affordances of the flipped classroom as perceived by the students. According to Creswell (2009), qualitative research is a means for exploring and understanding the meaning individuals or groups ascribe to a social or human problem.

\section{Participants}

The participants of the study comprised of 34 students recruited from University of Foreign Language Studies - The University of Danang, Vietnam to participate in a flipped English grammar course. They majored in the English language and were totally new to the flipped classroom. The students (age ranged between 19 and 21) were mostly female. At the end of the course, ten student participants were randomly selected for the semi-structured interviews.

\section{Instrument}

Qualitative data were gathered to address the research question through semi-structured interviews. They were carried out with ten students to explore the affordances of the flipped classroom teaching model. The questions used in the interviews were developed in accordance with the mediators of the Activity Theory framework.

\section{Data Collection}

Data collection took place during Semester 2 of the academic year 2017/2018. The English grammar course was taught during ten consecutive weeks. The course with ten grammatical topics was taught using the flipped classroom approach. Before coming to class, the students were asked to watch lesson videos posted on an online platform and do online quizzes to 
acquire the grammar rules. There was also an online forum created on the platform for the students to discuss the unclear grammatical points with their teacher and peers. During the face-to-face class meetings, they got involved in active learning activities in which they mostly applied what they had learned in real communicative practice.

At the end of the semester, ten student participants randomly selected were interviewed. The interviews were carried out in the Vietnamese language to enable the students to fully express their opinions. Each interview took approximately 15 minutes to complete. The interview transcripts were then audio-recorded, transcribed verbatim and translated into English for analysis.

\section{Data Analysis}

Thematic analysis was utilized to analyse the transcripts of the semi-structured interviews. According to Braun and Clarke (2006), thematic analysis is "a method for identifying, analysing and reporting patterns (themes) within data" (p. 79). Six phases of thematic analysis suggested by Marshall and Rossman (1999) were followed during the process of data analysis:

1. organise the data

2. generate categories or themes

3. code the data

4. test emergent understandings of the data

5. search for alternative explanations of the data

6. write-up the data analysis

The themes emerged from the data were clustered into four main categories, that is four mediators of the activity system: mediating artefacts or tools, rules, community and division of labour.

\section{Findings and Discussion}

As emerged from the data analysis, there were twelve identified themes which were clustered into four major categories or mediators. Figure 3 summarizes the affordances as perceived by the students under each mediator of the Activity Theory framework. 


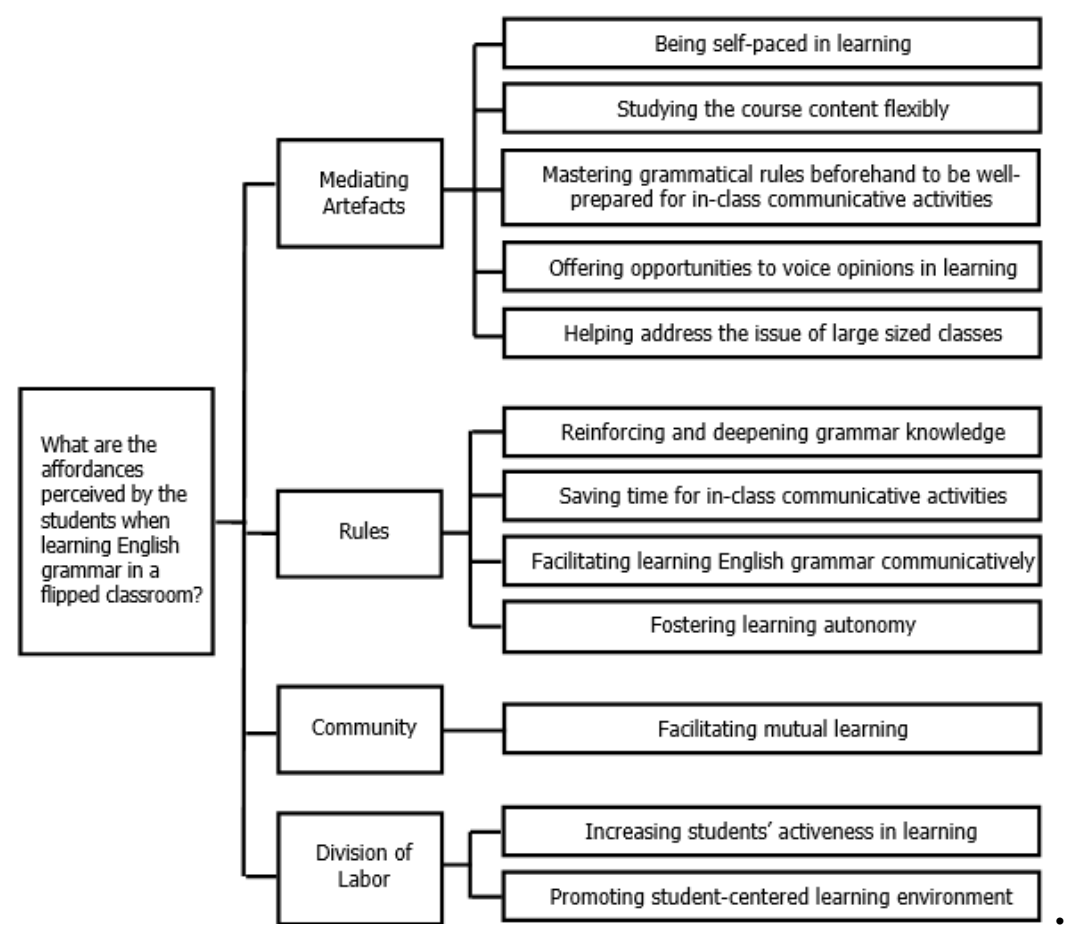

Figure 3: A Summary of Affordances of the Flipped Classroom

Detailed reports of the affordances are presented in the following sections.

\section{Mediating Artefacts}

There were five themes of affordances coming out under the mediator of tools. Firstly, the students revealed that the flipped classroom enabled them to become self-paced in learning when they could pause and re-play the lesson videos as many times as they wanted. As two students elaborated:

“... I could control my own learning process when studying through the lesson videos..."

“... Normally, I watched a lesson video once or twice. At first, I watched it carefully to catch all the grammar points. If I were not able to fully acquire the lesson content, I re-played it for better understanding..."

This finding aligns with those of the studies by Başal (2015) and Davies et al. (2013) when they concluded that students in the flipped classrooms could learn at their own pace with the help of educational technologies.

Secondly, the flipped class students were able to study the course content flexibly. Some students stated they could learn the lesson content anytime and anywhere they wanted during the pre-class session:

“... What I liked most about this learning format is the flexible time...."

"... In the flipped classroom, I could take control of learning time according to my own

schedule. I usually learned at home or at my part-time workplace when I were free..."

This affordance seems to meet the needs of "digital native" students who are familiar with digital devices such as computers, tablets or smartphones (Goodwin \& Miller, 2013).

Thirdly, the students in the flipped English grammar class were able to master grammatical rules in advance to be well-prepared for during-class communicative activities. As two students commented: 
“... The digital lessons and the online quizzes really helped me learn the grammatical points at home..."

"... This class offered me the chance to acquire the grammar points of the lessons at home.

So, I had a good preparation before coming to class for practice time. All the in-class practice activities helped me to master English grammar..."

The result confirms the findings by Thaichay and Sitthitikul (2016). The flipped classroom approach creates a suitable learning environment for students to improve both of their grammar knowledge and grammar use.

Fourthly, the students said that they were provided with the chance to voice their opinions when learning in this flipped classroom, as some following excerpts:

“... If I do not understand anything, I can talk to my teacher and my friend both at home and in class..."

"... The online forum allowed me to discuss any unclear grammar points with my friends..."

During the discussions with their teacher and their peers, students could learn from each other to improve their English grammar.

Finally, most of the students indicated that the flipped classrooms could help tackle the issue of large-sized classes. Some responded:

“... There are too many students in my class, but it doesn't really matter...”

“...Now in this flipped course, large class size was not a big problem because I could watch the video lectures at home..."

This affordance is a possible solution to the problem of big class size currently existing in many educational settings in Vietnam. Thanks to educational technologies, students can all acquire grammar knowledge as lectures are moved out of classes.

\section{Rules}

With regards to the rules in the flipped classroom, four themes regarding the affordances were discovered. First of all, the students stated that this teaching model helps reinforce and deepen their grammar knowledge, as some elaborated in the following excerpts:

"... I think that learning new grammatical points in advance at home enabled us to deepen and memorize the knowledge longer..."

“... As I said before, learning the grammar rules beforehand at home and then doing the exercises in groups and practice them in communicative activities during class time made the grammatical structures to be deeply engraved in my mind..."

This result is consistent with those by Riendeau (2012) who found that the flipped classroom provided students with the opportunities to clarify and deepen what they had learned in advance.

Also, the flipped classrooms saved time for communicative activities during class meetings. Two students commented as follows:

"... We did not waste class time on lectures. And then we practiced more with the communicative activities..."

“... we have more time to practice what we have learned beforehand in communicative activities..." 
More in-class time results in more opportunities for learning English grammar communicatively. This finding echoes the research by Al-Harbi and Alshumaimeri (2016) and Hung (2015).

In addition, the flipped classroom, as perceived by the students, facilitated learning English grammar communicatively. Some interviewees responded:

“... We have more different practice activities to do as compared to the traditional class..."

“... Now, the in-class communicative activities help me to easily apply the grammar structures in speaking..."

The communicative activities during the in-class session enabled the students to apply the grammatical rules they had learned beforehand in real situations, which resulted in the successful implementation of CLT in English grammar instruction (Nguyen et al., 2014).

Last but not least, another common theme emerged under this category is fostering learning autonomy. As two students mentioned:

“... But since attending this flipped class, I have become more self-aware of my learning when I have to remember to do pre-class activities..."

“... Through this class, I have improved my self-discipline and become more responsible for my learning..."

This result confirms the findings by Driscoll and Petty (2014) and Han (2015) that the flipped classroom leads to the promotion of students' learning autonomy.

\section{Community}

With respect to the community in the flipped classroom, it was discovered that this teaching model facilitated mutual learning. The following comments reflect this affordance of the approach.

"... I think this flipped class is very interesting and convenient. We can learn from each other in this class..."

“... If I am unclear of any grammar points, I can easily ask and discuss my friends and even with my teacher..."

In the learning environment created by this teaching model, students are offered more opportunities to exchange ideas concerning the lesson content with their classmates and their teacher. Accordingly, they would learn from each other to acquire the grammatical knowledge and improve their grammar use.

\section{Division of Labour}

Under the category of division of labour, two themes emerged from the data are the increase of their activeness in learning and the promotion of student-centred learning environment. One student confessed that the flipped classroom transformed them into more active learners:

“... In the traditional classes I have attended before, I mostly work during the face-to-face meetings... It's a bit passive. But in this class, we are required to learn the grammar points at home through the videos first. When coming to class, we review them and do practice communicative activities in pairs or in groups. I really like it because I find more active in learning."

This finding is similar to the view by Saulnier (2008) that the students become more active in the flipped classrooms. 
Also, this pedagogical model was considered as promoting student-centred learning environment. Two students elaborated:

“... In the class, the teacher doesn't deliver lectures but mentor and guide during the learning activities..."

"... But in this flipped class, learning through the online platform helps me become more active and understand the lesson better. The in-class activities are very interesting and make me more engaged in learning..."

Accordingly, students in the flipped classrooms could get more independent and effectively employ educational technologies. Learning in this student-centred environment would well prepare them to become life-long learners with $21^{\text {st }}$ century skills in the future.

\section{Conclusion}

Apparently, flipped classroom has proved to be a promising teaching approach in the field of English grammar instruction, especially in the Vietnamese educational context. It is the structure of the flipped classroom that results in a variety of affordances as perceived by the students and makes a contribution to its effectiveness in the improvement of their learning achievement and learning motivation. Depending on the existing conditions such as teachers' competence of using ICT in EFL teaching, institutions' Internet access and ICT infrastructure and students' ICT computer literacy, teachers should consider adopting this innovative teaching method to plan and design their flipped classes in order to help their students improve their English proficiency in general and grammar knowledge as well as grammar use in particular.

\section{References}

Ahmed, M. A. E. A. S. (2016). The effect of a flipping classroom on writing skill in English as a foreign language and students' attitude toward flipping. US-China Foreign Language, 14(2), 98-114.

Al-Harbi, S. S., \& Alshumaimeri, Y. A. (2016). The flipped classroom impact in grammar class on EFL Saudi secondary school students' performances and attitudes. English Language Teaching, 9(10), 60-80.

Albert, M., \& Beatty, B. J. (2014). Flipping the classroom applications to curriculum redesign for an introduction to management course: Impact on grades. Journal of Education for Business, 89(8), 419-424.

Baker, J. W. (2000). The "Classroom Flip": Using web course management tools to become the guide by the side. In J. A. Chambers (Ed.), Proceedings of the 11 th International Conference on College Teaching and Learning (pp. 9-17). Jacksonville, FL: Florida Community College at Jacksonville.

Başal, A. (2015). The implementation of a flipped classroom in foreign language teaching. Turkish Online Journal of Distance Education, 16(4), 28-37.

Bishop, J., \& Verleger, M. A. (2013). The Flipped Classroom: A Survey of the Research. In 2013 ASEE Annual Conference \& Exposition. Atlanta, Georgia.

Braun, V., \& Clarke, V. (2006). Using thematic analysis in psychology. Qualitative Research in Psychology, 3(2), 77-101.

Brunsell, E., \& Horejsi, M. (2013). Flipping your classroom in one "Take." The Science Teacher, 80(3), 8.

Chen Hsieh, J., Wu, W., \& Marek, M. (2017). Using the flipped classroom to enhance EFL learning. Computer Assisted Language Learning, 30(1-2), 1-21. 
Creswell, J. (2009). Research design: Qualitative, quantitative, and mixed methods approaches (3rd ed.). Thousand Oaks: Sage Publications.

Davies, R. S., Dean, D. L., \& Ball, N. (2013). Flipping the classroom and instructional technology integration in a college-level information systems spreadsheet course. Educational Technology Research and Development, 61(4), 563-580.

Driscoll, T., \& Petty, K. (2014). Student-driven education with flipped learning \& 20-time. In L. Kyei-Blankson \& E. Ntuli (Eds.), Practical applications \& experiences in K-20 blended learning environments (pp. 120-136). Hershey, PA: Information Science Reference.

Egbert, J., Herman, D., \& Lee, H. (2015). Flipped instruction in English language teacher education: A design-based study in a complex, open-ended learning environment. TESL-EJ, 19(2), 1-23.

El-Bassuony, J. M. (2016). The effectiveness of flipped learning in developing English grammatical performance of underachieving language learners at the secondary stage. International Journal of English Language Teaching, 4(8), 76-102.

Engestorm, Y. (1987). Learning by expanding: An activity theoretical approach to developmental research. Helsinki: Orienta-Konsulti.

Gilboy, M. B., Heinerichs, S., \& Pazzaglia, G. (2015). Enhancing student engagement using the flipped classroom. Journal of Nutrition Education and Behavior, 47(1), 109-114.

Goodwin, B., \& Miller, K. (2013). Research says evidence on flipped classrooms is still coming in. Educational Leadership, 70(6), 78-80.

Han, Y. J. (2015). Successfully flipping the ESL classroom for learner autonomy. NYS TESOL Journal, 2(1), 98-109.

Hasan, H. (1998). Activity Theory: A basis for the contextual study of Information Systems in organisations. In H. Hasan, E. Gould, \& P. N. Hyland (Eds.), Information Systems and Activity Theory: Tools in Context (pp. 19-38). Wollongong: University of Wollongong Press.

Heo, G. M., \& Lee, R. (2013). Blogs and social network sites as activity systems: Exploring adult informal learning process through Activity Theory framework. Educational Technology \& Society, 16(4), 133-145.

Hung, H.-T. (2015). Flipping the classroom for English language learners to foster active learning. Computer Assisted Language Learning, 28(1), 81-96.

Kang, N. (2015). The comparison between regular and flipped classrooms for EFL Korean adult learners. Multimedia-Assisted Language Learnin, 18(3), 41-72.

Le, H. T. (2013). ELT in Vietnam general and tertiary education from second language education perspectives. VNU Journal of Foreign Studies, 29(1), 65-71.

McLaughlin, J. E., Roth, M. T., Glatt, D. M., Gharkholonarehe, N., Davidson, C. A., Griffin, L. M., Mumper, R. J. (2014). The flipped classroom: A course redesign to foster learning and engagement in a health professions school. Academic Medicine, 89(2), 236-243.

Morf, M. E., \& Weber, W. G. (2000). I/O Psychology and the Bridging Potential of A. N. Leont'ev's Activity Theory. Canadian Psychology May, 41, 81-93.

Nguyen, H. T., Warren, W., \& Fehring, H. (2014). Factors affecting English language teaching and learning in higher education. English Language Teaching, 7(8), 94-105.

Pape, L., Sheehan, T., \& Worrell, C. (2012). How to do more with less: Lessons from online learning. Learning \& Leading with Technology, 39(6), 18-22.

Pham, T. H. T. (2011). Contrasting roles: Teacher and students in cooperative learning and Confucian heritage culture (CHC) classes. Experiments in Education, 39(3), 55-62.

Riendeau, D. (2012). Flipping the Classroom. The Physics Teacher, 50(8), 507-507. 
Sung, K. (2015). A case study on a flipped classroom in an EFL content course. MultimediaAssisted Language Learning, 18(2), 159-187.

Thaichay, T., \& Sitthitikul, P. (2016). Effects of the flipped classroom instruction on language accuracy and learning environment: A case study of Thai EFL Upper-secondary school students. Rangsit Journal of Educational Studies, 3(2), 35-64.

Tran, T. T. Q. (2017). Students' perceptions of flipped model on Facebook for educational purposes. IOSR Journal of Research \& Method in Education, 7(3), 7-14.

Tran, V. H., Yellishetty, M., Ngo, T. T., Patil, A., \& Le, T. H. (2017). The application of flipped classroom in teaching university students: A case study from Vietnam. International Journal of Quality Assurance in Engineering and Technology Education, 6(1), 40-52.

Verenikina, I. (2001). Cultural-Historical Psychology and Activity Theory in Everyday Practice. In H. Hasan, E. Gould, P. Larkin, \& L. Vrazalic (Eds.), Information Systems and Activity Theory: Volume 2 Theory and Practice (pp. 23-38). Wollongong: University of Wollongong Press.

Yang, C. C. R. (2017). An investigation of the use of the 'Flipped classroom' pedagogy in secondary English language classrooms. Journal of Information Technology Education: Innovations in Practice, 16, 1-20. 